\title{
Life cycle assessment of cement production with alternative fuels usage in Indonesia
}

Arief Setiawan $^{\mathrm{a}}$, Moh. Yanuar Jarwadi Purwanto ${ }^{\mathrm{b}}$, Kiman Siregar $^{\mathrm{c}}$

${ }^{a}$ Study Program of Natural Resources and Environmental Management, Graduate School, IPB University, Baranangsiang Campus IPB Bogor, 16144, Indonesia [+62 8111637228]

${ }^{\mathrm{b}}$ Department of Civil and Environmental Engineering, Faculty of Agricultural Engineering, IPB University, IPB Dramaga Campus Bogor, Indonesia [+62 8121104145]

${ }^{\mathrm{c}}$ Department of Agricultural Engineering, Faculty of Agriculture, Syiah Kuala University, Banda Aceh, Indonesia [+62 8111954822]

\section{Article Info:}

Received: 28 - 08 - 2021

Accepted: 18 - $10-2021$

\section{Keywords:}

Biomass, cement, GWP, LCA, refuse-derived fuel

\section{Corresponding Author:}

Arief Setiawan

Study Program of Natural

Resources and Environmental

Management, Graduate School,

IPB University;

Tel +628111637228

Email:

arief_setiawan@apps.ipc.ac.id

\begin{abstract}
Climate change has been a great issue in global nowadays. One of the contributors of global warming caused by cement manufacturing. The cement industry is a highly intensive energy, resource-consuming, and carbon emission industry. This study aimed to develop a life cycle assessment in cement production to improve the best available production techniques for environmental sustainability. The scope of the study covers mining extraction to processing of Cement (cradle to gate). The study showed that the value of 1 ton of Cement has global warming potential impact value $760.11 \mathrm{~kg} \mathrm{CO}_{2}$ eq, acidification potential impact value $1.32 \mathrm{~kg} \mathrm{SO}$-eq, photochemical oxidant creation potential impact value $0.0508 \mathrm{~kg} \mathrm{C}_{2} \mathrm{H}_{4}$-eq, human toxicity potential impact value $123.97 \mathrm{~kg}$ 1.4-DB-eq, and abiotic depletion potential impact value $2181.75 \mathrm{MJ}$. The result data shows that the highest contributor of impact value is in the kiln unit. The energy used in the kiln process unit contributes $92.46 \%$ of the total energy intensity in the cement production process. The results also showed that the energy was required to produce 1 ton cement production was 3.27 GJ, with the kiln process unit having the highest energy used contribution with a value of $3.03 \mathrm{GJ} / \mathrm{ton}$ product. The study comprises four scenarios to cover the simulation emission impact of fuels in cement manufacturing using alternative fuels and refuse derived fuels. The scenarios were intended to acknowledge the best-recommended practice of fuel compositions in the hotspots area.
\end{abstract}

How to cite (CSE Style $8^{\text {th }}$ Edition):

Setiawan A, Purwanto MYJ, Siregar K. 2021. Life cycle assessment of cement production with alternative fuels usage in Indonesia. JPSL 11(3): 474-489. http://dx.doi.org/10.29244/jpsl.11.3.474-489.

\section{INTRODUCTION}

The cement industry consumes natural resources (raw materials), energy (heat and electricity), and fossil fuel sources (e.g., coal, petroleum coke). This means that cement production consumes non-renewable raw materials, which are the basic constituents of the product, and fossil fuels required for the heating process. Cement production was reported responsible for $5 \%$ of global anthropogenic $\mathrm{CO}_{2}$ emissions and $7 \%$ of industrial fuel use (Chen et al., 2010).

Several studies have been conducted to evaluate $\mathrm{CO}_{2}$ emissions, energy consumption, and emissions using Life Cycle Assessment (Harjanto et al., 2012; Stafford and Fernanda, 2015; Nugraha, 2017; Cankaya, and Pekey, 2018; Maharani, 2019). Life Cycle Assessment (LCA) is a suitable tool for sustainability assessment 
that provides quantitative and overall information on the investigated system's resource consumption and environmental emissions (Rebitzer et al., 2004). LCA study is referred to the ISO 14040 (2016) and ISO 14044 (2017) standards. LCA in the cement industry will be a mechanism for assessing the environmental impact of cement production and its associated supply chain. $\mathrm{CO}, \mathrm{NO}_{\mathrm{x}}$, and $\mathrm{SO}_{2}$ emissions from the cement industry contribute significantly to the greenhouse effect and acid rain (Zhang et al., 2011). Cement contains a clinker formed when limestone raw material is burned at high temperatures in a cement kiln. In this process i.e., calcination, the calcium carbonate is decomposed, and $\mathrm{CO}$ and $\mathrm{CO}_{2}$ emissions are generated.

Calcination is a very important process from a climatic point of view because the carbon bonds in minerals transform into $\mathrm{CO}_{2}$ (Huntzinger and Eatmon, 2009). In addition, this process usually causes about $50 \%$ of the total $\mathrm{CO}_{2}$ emissions that come from cement production. Most residual emissions come from burning fuel in the kiln (Nadal et al., 2009). The study was applied in the clinker and the cement production. It was intended to analyze the direct and indirect impacts of mining resources, production of cement, and electricity use (Gabel et al., 2004. The clinker production process has a significant environmental impact compared to the raw material preparation and the final cement production. These environmental impacts are associated with direct kiln emissions and primary fuel production. In addition, direct kiln emissions are a significant contributor to five major impact categories i.e., global warming, terrestrial ecotoxicity, photochemical oxidation, acidification, and eutrophication (Chen et al., 2010).

Indonesia has committed to reducing greenhouse gas (GHG) emission levels by $29 \%$ with its effort and $41 \%$ with international assistance at the G-20 meeting in Pittsburg, United States. The commitment statement has been stated in Indonesian Government (2016). This realization of commitment was previously in Indonesian Government (2011) on the national action plan to reduce greenhouse gas emissions in which mentioned the institutions responsible for the national GHG emission reduction target, policy directions for each sector, and mitigation actions that may be implemented to achieve the national GHG emission reduction target (Indonesian Cement Association, 2018). To support the reduction of GHG emissions in the cement industry, Indonesian Government (2012) has issued a roadmap for reducing $\mathrm{CO}_{2}$ emissions in the cement industry in Indonesia.

There are three (3) main objectives within the study. The first objective was to find hotspots by assessing the production flow process per tonne of cement product and the environmental impact according to the impact criteria. The second objectives of the study were to assess the impact of the existing environment by comparing the alternative scenarios for recommendations of continuous improvement. The third objective of the study was determining the internal and external factors of the company's environmental management as well as the company's strategy in the context of environmental management (strategy formulation).

\section{METHOD}

\section{Research Location and Period}

The study was conducted in the PT XYZ Narogong Plant, Bogor Regency, West Java Province. The cement industry was chosen because the industry has a target to reduce greenhouse gas emissions. The study was located in a strategic place whereas it is surrounded by alternative fuels producer. Hence, the simulation of research can be performed due to the availability of source of alternative fuels. Field research was carried out from January 2020 to June 2020, followed by data processing and analysis on the IPB University Campus.

\section{Research Methods}

The study used two methods: Life Cycle Assessment (LCA) and Strengths Weaknesses Opportunities Threats (SWOT) analysis. The purpose of the LCA was to determine quantitative process data to determine hotspots points. This point will be the focal point for making improvements with several alternative scenarios for improvement recommendations. The SWOT analysis was intended to describe qualitatively and quantitatively the environmental management system to obtain a strategic formulation to support 
recommendations for improvement. The resume of data requirement and analysis method to reach the objective were shown in Table 1.

Table 1 Data and analysis methods

\begin{tabular}{|c|c|c|c|}
\hline \multirow{2}{*}{ Purpose } & \multicolumn{2}{|c|}{ Data } & Analysis Method \\
\hline & Scheme & Source & \\
\hline $\begin{array}{l}\text { 1. Assess the resulting production flow per } \\
\text { tonne of cement product and the } \\
\text { environmental impact according to the } \\
\text { impact criteria (Hotspots) }\end{array}$ & $\begin{array}{l}\text { Study of } \\
\text { literature, } \\
\text { field survey }\end{array}$ & $\begin{array}{l}\text { Journal, } \\
\text { PT XYZ } \\
\text { database }\end{array}$ & $\begin{array}{l}\text { Life cycle assessment } \\
\text { scope: cradle to gate }\end{array}$ \\
\hline $\begin{array}{l}\text { 2. Assessing the impact of the existing } \\
\text { environment by comparing alternative } \\
\text { scenarios for recommendations for } \\
\text { continuous improvement (Continuous } \\
\text { Improvement) }\end{array}$ & $\begin{array}{l}\text { Study of } \\
\text { literature, } \\
\text { field survey }\end{array}$ & $\begin{array}{l}\text { Journal, } \\
\text { PT XYZ } \\
\text { database }\end{array}$ & $\begin{array}{l}\text { Life cycle assessment } \\
\text { scope: cradle to gate }\end{array}$ \\
\hline $\begin{array}{l}\text { 3. Determine the internal and external } \\
\text { factors of the company's environmental } \\
\text { management as well as the company's } \\
\text { strategy in the context of environmental } \\
\text { management (Strategy Formulation) }\end{array}$ & $\begin{array}{l}\text { Study of } \\
\text { literature, } \\
\text { field survey }\end{array}$ & $\begin{array}{l}\text { Journal, } \\
\text { respondent } \\
\text { interview, } \\
\text { observation }\end{array}$ & $\begin{array}{l}\text { Strengths Weaknesses } \\
\text { Opportunities Threats } \\
\text { (SWOT) }\end{array}$ \\
\hline
\end{tabular}

The LCA study refers to the ISO 14040:2016 standard, which consists of 4 stages, firstly the definition of goals and scope (goal and scope definition), second the inventory analysis (life cycle inventory analysis), third the environmental impact assessment (life cycle impact assessment), and forth the interpretation (life cycle interpretation). The scope as boundary system of this study was limited to the cradle to gate system, which analyze the results of the existing (baseline) factory conditions and alternative scenarios from the use of fuel and energy to obtain interpretation. The cradle to gate boundary was chosen due to the availability of inventory data set in the field, which are only cover material extraction, manufacture process to packaging.

The research will use a basis of 1 ton of cement products for four (4) scenarios, namely: (1) 100\% Coal; (2) 75\% Coal and 25\% Alternative Fuel; (3) Coal 65\%, Alternative Fuel 25\% and Refuse Derive Fuels (RDF) $10 \%$; (4) Coal 55\%, Alternative Fuel 25\% and RDF 20\%. The percentage of alternative fuel used is used oil (5\%), industrial mixed waste (10\%), biomass (10\%) with a fixed composition of $25 \%$. The formula from RDF was obtained through the results of trials of PT XYZ with Gross Heating Value (GHV) and moisture content requirements (Paramita, 2018).

\section{Determination of Goals and Scope of LCA (goal and scope definition)}

According to ISO 14040, the first step is to determine the purpose and scope of the LCA. This was done prior to its implementation due to it has many variations of data and processes in the field. Therefore, a clear objective will make research more effective and efficient. Setting goals will have implications for the recipients of this study report so that the recipients of the information will have the same understanding of interpretation. The determination of the scope limits is based on the ISO 14025 (2006) standard to determine the Product Category Rules (PCR), which sets the system boundary in the LCA study. This study was conducted starting from the mining of raw materials, production processes until packaging. The system was divided into six subsystems of functional units, i.e. mining (raw material extraction), raw mill, coal mill, kiln, finish mill, packing. 


\section{Life Cycle Inventory Analysis}

The next step is an inventory of the required data for the LCA study of PT XYZ relates to the cement production flow. The data required is the mining results of lime, clay, silica sand, iron sand, gypsum, fly ash for raw materials. Data on the use of industrial diesel is needed as heavy equipment and transportation for the raw materials supplies, while for thermal energy is for fossil fuels and alternative fuels supplies. The electricity consumption data is obtained from every processing unit subsystem, namely mining data (Raw Material Extraction), Raw Mill, Coal Mill, Kiln, Finish Mill, Packing.

\section{Life Cycle Impact Assessment}

Life Cycle Impact Assessment begins with the selection of impact categories, category indicators, and characterization models. The classification of inventory data was carried out within the calculation of results. In this study the environmental impact assessment of LCA was based on the Centrum voor Milieuwetenschappen Leiden (CML) method. There are five (5) environmental impacts considered in the study, namely Global Warming Potential (GWP), Acidification Potential (AP), Photochemical Oxidation Potential (POCP), Human Toxicity Potential (HTP), and Abiotic Depletion Potential (ADP). This stage aims to find hotspots through analysis of the impact of each unit of the cement production process.

\section{Life Cycle Interpretation}

This stage is the evaluation stage of the entire LCA process. It discusses the suitability of the results with the predetermined objectives and scope, data inventory, and environmental impacts. The discussion was carried out to determine the correlation of the results of the impact analysis process. The LCA study will reveal the data factually on each subsystem manufacturing process on the resulting impact. This stage also analyzes the inventory data that causes the impact results and reveals the important things. After the process analysis finds improvements from the starting point and alternative scenarios, the improvement recommendations will be explained.

\section{SWOT Analysis}

Methods of data processing and data analysis using descriptive analysis with qualitative and quantitative descriptive. The qualitative descriptive analysis defines the company's vision, mission, and goals, and this analysis aims to describe the conditions faced by the company. The qualitative analysis is used to determine the company's strengths, weaknesses, opportunities, and threats. The analysis is used to describe alternative strategies, as well as product manufacturing mix strategies. In addition, qualitative descriptive analysis is also used to analyze data from competing companies and consumers of similar products. Meanwhile, the quantitative analysis was performed using the IFE (Internal Factor Evaluation) matrix, the EFE (External Factor Evaluation) matrix, and the SWOT matrix. According to David (2009), there are several stages in formulating strategies: the input stage, the matching stage, and the decision stage. However, in this study, researchers only conduct at the matching stage. After the matching stage, the researchers immediately developed a sustainable environmental management strategy.

\section{RESULTS AND DISCUSSION}

\section{Data Inventory LCA}

The limitation of the scope of the research is cradle to gate, whereas the focal point at the beginning of the material is taken to the clinkering then processed in the finish mill to become Cement to packing. The study used a unit function of 1-ton PCC (Portland Composite Cement) produced by a cement factory. The cement production process is divided into six process units: raw material extraction, raw mill, coal mill, kiln, finish mill and packing process units. The resume of calculated data inventory was shown in Table 2 as cement 
production inventory data. This data was collected at the field thru several division in the cement factory.

Table 2 describes about the inventory of cement data production in PT XYZ. The data set describes using tonnage of raw material, fuels for transportation, and electricity per ton cement. The amount of value was influenced by the quality of material and fuels. In the raw material, the quality of limestone is determined by $\mathrm{CaO}$ content within the $\mathrm{CaCO}_{3}$ material as received (Alfarizi et al., 2020). The rest of raw material is also determined by the quality of its content, e.g. clay $\left(\mathrm{Al}_{2} \mathrm{O}_{3}\right)$, silica sand $\left(\mathrm{SiO}_{2}\right)$, iron sand $\left(\mathrm{Fe}_{2} \mathrm{O}_{3}\right)$, fly ash bottom ash (Si-Al-Ca-Fe), and gypsum (Holcim, 2006). The fuel for transportation is determined by its distance, whereas the nearest source location of fuels will give advantage of fuel consumption. Coal was sourced from South Kalimantan, hence it provided the highest fuel consumption rather than transportation for raw material and alternative fuels. The electricity consumption is determined by equipment using electricity in the cement process, e.g. motor, conveyor, crusher, pumps, and other utilities.

Table 2 Cement production inventory data

\begin{tabular}{lcc}
\hline \multicolumn{1}{c}{ Raw Material } & Unit & Value \\
\hline Limestone & ton & 1.264 \\
Clay & ton & 0.171 \\
Silica & ton & 0.028 \\
Iron Sand & ton & 0.00656 \\
Fly Ash & ton & 0.059 \\
Gypsum & ton & 0.037 \\
Industrial Mix & ton & 0.390 \\
\hline Transportation & & \\
\hline Raw Material & ton & 1.260 \\
Coal & ton & 2.020 \\
Alternative fuels & ton & 0.020 \\
\hline Electricity & $\mathrm{kWh}$ & 107.200 \\
\hline Total Electricity & & \\
\hline
\end{tabular}

Note: Data per tonne of cement

Cement production requires a large amount of thermal energy. The main thermal fuel comes from coal and alternative fuels. Table 3 explains that the inventory data set has been simulated by using heat fuels as a basis in 1-ton cement production. The study comprises four (4) scenarios, namely: (1) 100\% Coal; (2) $75 \%$ Coal and 25\% Alternative Fuel; (3) Coal 65\%, Alternative Fuel 25\% and Refuse Derive Fuels (RDF) 10\%; (4) Coal 55\%, Alternative Fuel $25 \%$ and RDF $20 \%$. The target of scenario simulations was intended to reduce fossil fuels use and to increase alternative fuels use. The simulations were expected to find the best practice recommendation to improve environment impact from cement production.

Table 3 Cement production fuel inventory data

\begin{tabular}{lcccccc}
\hline \multicolumn{1}{c}{ Fuel } & Unit & Baseline & Scenario 1 & Scenario 2 & Scenario 3 & Scenario 4 \\
\hline Coal & ton & 0.1334 & 0.1620 & 0.1215 & 0.1053 & 0.0891 \\
Diesel (IDO) & ton & 0.0003 & - & - & - & - \\
Used oil & ton & - & - & 0.0034 & 0.0034 & 0.0034 \\
Mix Industrial Waste & ton & 0.0167 & - & 0.0170 & 0.0170 & 0.0170 \\
Rice Husk & ton & 0.0090 & - & 0.0123 & 0.0123 & 0.0123 \\
RDF & ton & - & - & - & 0.0203 & 0.0406 \\
\hline
\end{tabular}

Note: Data per tonne of cement 
Coal as conventional fuels and alternative fuels are used as heat energy in cement production. Given the high intensity of energy used by the clinker process, the calorific value of the material becomes the most important thing. The company obtained coal from South Kalimantan with of heating value (HV) $18.7 \mathrm{MJ} / \mathrm{kg}$ (Kartikasari, 2016). Industrial diesel oil with HV $38 \mathrm{MJ} / \mathrm{kg}$ comes from the state oil energy company located $56 \mathrm{~km}$ from the site (KLHK, 2012). In the scenario, the researcher replaces the use of IDO with used oil with $\mathrm{HV} 45.36 \mathrm{MJ} / \mathrm{kg}$ (Alsyehab, 2013), which has functioned as heating up for combustion in the kiln. The factory's location contains many industries that have waste suitable for use in cement co-processing with $\mathrm{HV}$ $15.30 \mathrm{MJ} / \mathrm{kg}$ (Boumanchar, 2018). Biomass of agricultural products comes from local agriculture which produces rice husks with HV $13.82 \mathrm{MJ} / \mathrm{kg}$ (Hernowo et al., 2017). This study was also designed to use Refuse Derived Fuel (RDF) with HV $14.92 \mathrm{MJ} / \mathrm{kg}$ as an additional variant in the use of alternative fuels (Paramita, 2018). This is because the area around the factory has a final disposal site for urban domestic waste from big cities around the location.

In worldwide, coal is used as the primary fuel burned in cement production, whereas cement kilns use about $120 \mathrm{~kg}$ of coal per tonne of Cement (IEA, 2010). Based on Table 4, then PT XYZ uses coal as fuel in cement production as much as $133 \mathrm{~kg}$ per tonne of Cement. The variant of coal use has influenced by the quality of coal. The various of coal types in the market which categorized by its calorific values e.g. Anthracite, Bituminous, Sub-bituminous and Lignite (Abrar et al., 2017). The highest calorific value being used, then the lesser amount of tonnage will be used. Alternative fuels are used in cement manufacture, which is intended to reduce global warming emissions (GWP). Several alternative fuels can be used through the co-processing, such as industrial waste products and rice husk waste (Holcim, 2006).

Table 4 Use of fuel for thermal energy

\begin{tabular}{|c|c|c|}
\hline Fuels (Kiln) & $\begin{array}{c}\text { Value } \\
\text { (ton/ton cement) }\end{array}$ & $\begin{array}{c}\text { Value } \\
\text { (kg/ton cement) }\end{array}$ \\
\hline Alternative Fuel & 0.025 & 25 \\
\hline Coal & 0.133 & 133 \\
\hline Total & 0.158 & 158 \\
\hline
\end{tabular}

Table 5 Use of diesel fuel (IDO)

\begin{tabular}{lc}
\hline \multicolumn{1}{c}{ Fuel (Kiln) } & $\begin{array}{c}\text { Value } \\
\text { (ton/ton cement) }\end{array}$ \\
\hline Heavy Equipment Use and Transportation & 1.140 \\
Alternative Fuels and Materials (AFR) & 1.280 \\
Coal Mining and Shipping & 2.020 \\
Kiln & 0.390 \\
\hline Total & 4.830 \\
\hline
\end{tabular}

Note: Data per tonne of cement

Table 6 IDO fuel use for coal procurement

\begin{tabular}{lcl}
\hline \multicolumn{1}{c}{ Fuel (Kiln) } & $\begin{array}{c}\text { Score } \\
\text { (ton/ton coal) }\end{array}$ & \multicolumn{1}{c}{ Citation } \\
\hline Coal Mining & 7.910 & Qola, 2020 \\
Shipping & 6.390 & Yunianto, 2018 \\
Transportation & 0.870 & Octova, 2019 \\
\hline
\end{tabular}

Note: Data per tonne of coal 
Based on Table 5, the calculation results of diesel fuel of cement use 4.83 liters/ton cement. Whereas it is found that diesel fuel consumption for coal mining and shipping has the highest value. The calculations that caused this includes coal mining, shipping, and transportation from the site to the PT XYZ location. Table 6 below is a simulation of the calculation of coal procurement per unit of coal used by PT XYZ with the origin of the mine from South Kalimantan-Indonesia.

Based on inventory data, it can be seen that the use of electricity is one source of energy for energy supply. According to the IEA (IEA, 2010), electricity consumption ranges from 90 to $120 \mathrm{kWh} / \mathrm{t}$ cement, except for the United States, Mexico, and Canada where Figures are almost all above $120 \mathrm{kWh} / \mathrm{t}$ cement. Electrical energy is used as source of energy to produce power for industrial machine performance and support production support power needs. Hence based on Table 7, the cement manufactory uses $107.2 \mathrm{kWh} /$ ton cement which is still in range of common electricity use in worldwide based on IEA 2010.

7 Use of electrical energy

\begin{tabular}{lc}
\hline \multicolumn{1}{c}{ Process } & $\mathrm{kWh} / \mathrm{t}$ cement \\
\hline Raw Material Extraction & 2464 \\
Raw Mill & 21285 \\
Coal Mill & 4797 \\
Kiln & 38925 \\
Finish Mill & 36936 \\
Packing & 2788 \\
\hline Total & 107200 \\
\hline
\end{tabular}

Note: Data per tonne of cement

Table 8 shows the consumption of energy that has been used to the processing unit. In general, the energy required to produce per ton of cement product PT XYZ is $3.27 \mathrm{GJ} / \mathrm{t}$ cement, with the Kiln process unit having the highest contribution to energy use with a value of $3.03 \mathrm{GJ} / \mathrm{t}$ cement. The global thermal energy intensity of kilns is estimated to have dropped to around $3.4 \mathrm{GJ} / \mathrm{t}$ in 2018, an average annual decline of $0.5 \%$ since 2014. Fossil fuels are used mostly for energy in the cement sector, with bioenergy and biomass only $3 \%$ of the heat energy used in 2018 (IEA, 2020). The result data in Table 8 has shown that PT XYZ energy consumption was at below worldwide data. PT XYZ energy intensity described the process system that it has reach effective and efficiency in producing Cement.

Table 8 Energy intensity of PT XYZ

\begin{tabular}{lccccc}
\hline \multirow{2}{*}{ Process Unit } & \multicolumn{2}{c}{ Intensity $(\mathrm{GJ} /$ ton of Cement) } & \multicolumn{2}{c}{ Total } \\
\cline { 2 - 5 } & Electricity & Heat & IDO & GJ/ton & $\%$ \\
\hline Raw Material Extraction & 0.01 & 0.00 & 0.001 & 0.01 & 0.31 \\
Raw Mill & 0.08 & 0.00 & 0.000 & 0.08 & 2.34 \\
Coal Mill & 0.02 & 0.00 & 0.000 & 0.02 & 0.53 \\
Kiln & 0.14 & 2.88 & 0.012 & 3.03 & 92.46 \\
Finish Mill & 0.13 & 0.00 & 0.000 & 0.13 & 4.06 \\
Packing & 0.01 & 0.00 & 0.000 & 0.01 & 0.31 \\
\hline Total & 0.39 & 2.88 & 0.0136 & 3.27 & 100.00 \\
\hline
\end{tabular}

\section{Life Cycle Impact Assessment (LCIA)}

After collecting inventory data, including raw material mining, fuel classification, and electricity usage through the inventory analysis stage, the next step is to conduct a life cycle impact analysis. The stages of life cycle impact analysis (LCIA) include selecting impact categories, classification, and selection of 
characterization. After selecting the impact category, the next step is data grouping (classification). This stage is important to process the data into calculations with the characterization model later. In this LCA study, the Centrum voor Milieuwetenschappen Leiden (CML) method was chosen as a characterization factor.

The Cement produced by this process unit shows a global warming potential (GWP) value $760.11 \mathrm{~kg} \mathrm{CO}$ eq/ton of Cement. Refer to Table 9, then it can be seen that the highest processing unit that contributes to the potential effects of global warming is in the kiln process unit of $673.74 \mathrm{~kg} \mathrm{CO}_{2}$-eq/ton of Cement with a percentage of $88.64 \%$. The use of energy intensity in the kiln process unit results in high material emissions, electricity usage emissions, and heat energy emissions compared to other process units. The highest Acidification Potential (AP) was produced by cement plant activities using 100\% coal as fuel with an AP value of $1.43 \mathrm{~kg} \mathrm{SO}$-eq/ton of Cement. By combining the use of coal and alternative fuels and RDF, scenarios 2, 3, and 4 show that the AP value is decreasing respectively with a value of $1.28 \mathrm{~kg} \mathrm{SO}_{2}$-eq/ton cement, $1.23 \mathrm{~kg}$ $\mathrm{SO}_{2}$-eq/ton product, and $1.19 \mathrm{~kg} \mathrm{SO}{ }_{2}$-eq/ton of Cement.

Table 9 Impact assessment of cement products PT XYZ (baseline)

\begin{tabular}{lccccc}
\hline \multicolumn{1}{c}{ Process Unit } & $\begin{array}{c}\mathrm{GWP} \\
\mathrm{kg} \mathrm{CO}_{2} \text { eq }\end{array}$ & $\begin{array}{c}\mathrm{AP} \\
\mathrm{kg} \mathrm{SO}_{2} \text { eq }\end{array}$ & $\begin{array}{c}\mathrm{POCP} \\
\mathrm{kg} \mathrm{C}_{2} \mathrm{H}_{4} \text { eq }\end{array}$ & $\begin{array}{c}\mathrm{HTP} \\
\mathrm{kg} \mathrm{1.4-DB} \text { eq }\end{array}$ & $\begin{array}{c}\text { ADP } \\
\mathrm{MJ}\end{array}$ \\
\hline Raw Material Extraction & 4.28 & 0.02 & 0.0006 & 1.24 & 45.42 \\
Raw Mill & 17.23 & 0.07 & 0.0025 & 9.58 & 416.07 \\
Coal Mill & 16.02 & 0.07 & 0.0047 & 14.43 & 184.60 \\
Kiln & 673.74 & 0.94 & 0.0360 & 72.39 & 983.30 \\
Finish Mill & 45.90 & 0.21 & 0.0066 & 24.67 & 521.66 \\
Packing & 2.95 & 0.01 & 0.0004 & 1.66 & 30.70 \\
\hline Total & 760.11 & 1.32 & 0.0508 & 123.97 & 2181.75 \\
\hline
\end{tabular}

Note: Data per tonne of cement. GWP: global warming potential, AP: acidification potential, POCP: photochemical oxidation creation potential, HTP: human toxicity potential, ADP: abiotic depletion potential

This cement production process has a potential value for the formation of POCP of $0.0508 \mathrm{~kg} \mathrm{C}_{2} \mathrm{H}_{4}$-eq/ton cement. Based on the data on the potential impact of photochemical formation, it can be seen that the highest contributor process unit is the kiln process unit with a value of $0.0360 \mathrm{~kg} \mathrm{C}_{2} \mathrm{H}_{4}$-eq/ton cement or $70.98 \%$. The high value caused by the high of energy intensity which uses in various mixtures of fossil fuels and alternative fuels containing $\mathrm{C}_{2} \mathrm{H}_{4}$ compounds. Based on the Table data above, it can be seen that the highest processing unit that contributes to the impact of HTP is in the Kiln process unit with a value of $72.39 \mathrm{~kg} 1.4-\mathrm{DB}$ eq/ton of product or about $56.46 \%$ of the total. The high impact of HTP on the kiln process unit is caused by the emissions resulting from alternative fuels other than coal fuel in this process. Data on the potential impact of Abiotic Source Depletion (ADP) shows that the highest processing unit that contributes to the impact of ADP is in the Kiln process unit with a value of $983.30 \mathrm{MJ} /$ ton cement or $45.07 \%$. The high value of the potential impact of the depletion of abiotic resources on the kiln process unit is caused by the high energy intensity requiring the extraction of fuel from fossil fuels and alternative fuels. Based on the overall potential impact data, the highest contributor is produced by the kiln process unit.

\section{Life Cycle Assessment Interpretation}

The result data from the simulation results of the impact calculation show that all hotspots come from the Kiln process unit. The simulation is run based on inventory data collected by researchers in the field. In Accordance with the second research objective then this study also conducted a study of alternative scenarios for recommendations for the continuous improvement of PT XYZ in managing hotspots. This constant improvement simulation focuses on hotspots, namely increasing alternative fuels and reducing fossil fuels. The hypothesis is that changing the amount of composition by adding alternative fuel variants will minimize 
the impact value. After baseline LCA study is completed, then the next step is conducting impact assessment of alternative scenario. This step is intended to compare the results of the existing (baseline) factory conditions and alternative scenarios from the use of fuel and energy for interpretation. The following are data results from SIMAPRO ${ }^{\circ}$, which was simulated by an alternative scenario data inventory.

The results in Table 10 show that the largest GWP was produced by cement factory activities using 100\% coal as fuel with a total GWP value of $789.35 \mathrm{~kg} \mathrm{CO}_{2}$-eq/ton of product. This data is intended as a trial of the current system using $100 \%$ coal. The value of GWP that uses a mixture of fossil fuels, coal, and alternative fuels has various values, so the target for reducing fossil fuels will affect the GWP value.

Table 10 Impact assessment of alternative scenario cement products PT XYZ

\begin{tabular}{lccccc}
\hline \multirow{2}{*}{ Impact Category } & \multicolumn{5}{c}{ Scenario } \\
\cline { 2 - 6 } & Baseline & Scenario 1 & Scenario 2 & Scenario 3 & Scenario 4 \\
\hline $\mathrm{GWP}\left(\mathrm{kg} \mathrm{CO}_{2}\right.$ eq $)$ & 760.11 & 789.35 & 741.21 & 749.39 & 757.41 \\
$\mathrm{AP}\left(\mathrm{kg} \mathrm{SO}_{2}\right.$ eq) & 1.32 & 1.43 & 1.28 & 1.23 & 1.19 \\
$\mathrm{POCP}\left(\mathrm{kg} \mathrm{C}_{2} \mathrm{H}_{4}\right.$ eq $)$ & 0.0508 & 0.0506 & 0.0505 & 0.0494 & 0.0482 \\
$\mathrm{HTP}(\mathrm{kg} 1.4-\mathrm{DB}$ eq $)$ & 123.97 & 130.87 & 119.69 & 117.74 & 113.59 \\
$\mathrm{ADP}(\mathrm{MJ})$ & 2181.75 & 2355.38 & 2212.08 & 2194.98 & 2170.08 \\
\hline
\end{tabular}

Note: Data per tonne of cement

An important issue regarding the potential impact of global warming can be seen in that the emission value of this global warming potential is the sum of emissions related to material (process), emissions related to the heat energy source used, and electrical energy. According to Lehne and Preston (2018), 90\% of the distribution of the impact of emissions produced by cement factories in the world comes from the activities of the Kiln process unit, both from the process $(50 \%)$ and the heat energy used (40\%) and the remaining $10 \%$ comes from extraction activities, raw material, grinding, raw material preparation, cooling, and mixing. In accordance Table 11 and Figure 1 then the data results show $88 \%$ of global warming potential emissions come from the activities of the kiln process unit, with 50\% produced by the process and $38 \%$ from the use of thermal energy. The use of IDO shows a value of 1\%, and this Figure is obtained from the use of industrial diesel fuel for transportation and heavy equipment to obtain materials.

Table 11 Distribution of GWP emission impacts

\begin{tabular}{lccc}
\hline \multicolumn{1}{r}{ Emission Source } & Process Unit & Value & Percent (\%) \\
& & $\mathrm{kg} \mathrm{CO}_{2}$-eq/ton & 1 \\
Transportation (IDO) & Non-Kiln & 10.01 & 11 \\
Electricity & Kiln and non-Kiln & 82.40 & 38 \\
Heat (Heat) & Kiln & 289.65 & 50 \\
Materials (Process) & Kiln & 378.05 & 100 \\
\hline \multicolumn{1}{c}{ Total } & & 760.11 & \\
\hline
\end{tabular}

Note: Data per tonne of cement

Based on Table 10 shows the highest Acidification Potential (AP) was produced by cement plant activities using $100 \%$ coal as fuel with an AP value of $1.43 \mathrm{~kg} \mathrm{SO}_{2}$-eq/ton of Cement. By combining the use of coal and alternative fuels as well as RDF, scenarios 2, 3, and 4 show that the AP value is decreasing, namely $1.28 \mathrm{~kg}$ $\mathrm{SO}_{2}$-eq/ton cement, $1.23 \mathrm{~kg} \mathrm{SO}$-eq/ton cement, and $1.19 \mathrm{~kg} \mathrm{SO}_{2}$-eq/ton of Cement. According to Hacatoglu (2014), acidification potential refers to compounds that are precursors of acid rain. These include sulfur dioxide $\left(\mathrm{SO}_{2}\right)$, nitrogen oxides (NOx), nitrogen monoxide $(\mathrm{NO})$, nitrogen dioxide $\left(\mathrm{N}_{2} \mathrm{O}\right)$, and various other substances. The acidification potential is usually characterized by the $\mathrm{SO}_{2}$ equivalence. This acid gas is generally released 
into the atmosphere due to the combustion of fuel. Research on the chemical composition of coal ash (Damayanti, 2018) shows the value of sulfur oxides contained in coal. It is assumed that the cause of the decline in the value of AP is decreasing along with the reduction in the use of coal fuel. As Figure 1 shows, scenario 4 has the maximum value in this study with a decrease of $9.85 \%$.

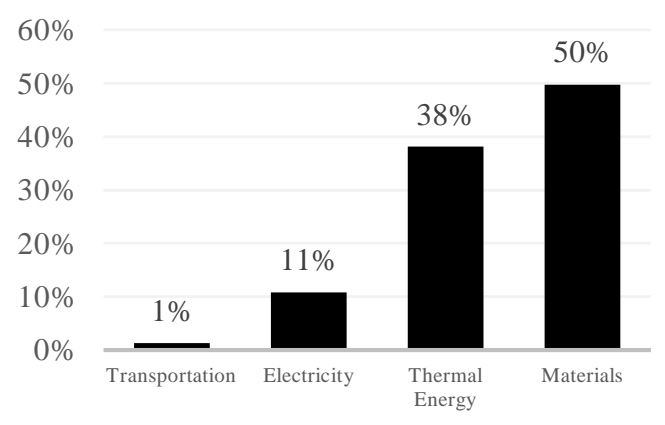

Figure 1 Distribution of GWP emission impacts

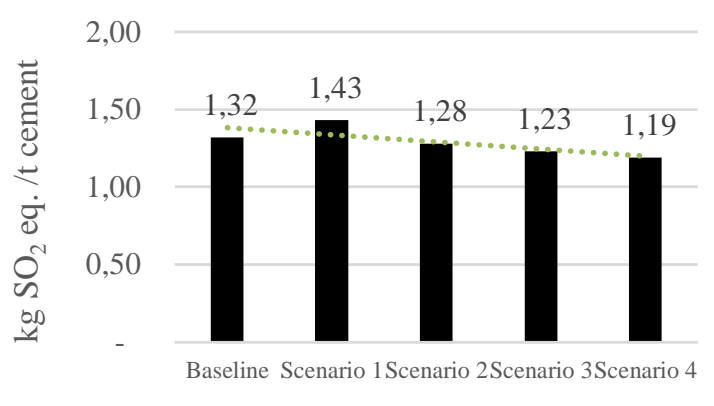

Figure 2 Result of acidification potential (AP)

In Accordance with Table 10, the highest value of Photochemical Oxidant Creation Potential (POCP) was generated by cement factory activities at baseline with a POCP yield value of $0.0508 \mathrm{~kg} \mathrm{C}_{2} \mathrm{H}_{4}$-eq/ton cement. By combining the use of coal fuel and alternative fuels and RDF, scenarios 2, 3, and 4 show a decreasing respectively, with POCP value $0.0506 \mathrm{~kg} \mathrm{C}_{2} \mathrm{H}_{4}$-eq/ton cement, $0.0494 \mathrm{~kg} \mathrm{C}_{2} \mathrm{H}_{4}$-eq/ton cement, and $0.0482 \mathrm{~kg}$ $\mathrm{C}_{2} \mathrm{H}_{4}$-eq/ton cement. In this study, scenario 4 has the maximum value with a decrease of $5.11 \%$. These photochemical oxidants are produced in the atmosphere from sunlight reacting with hydrocarbons and nitrogen oxides. They can cause or worsen health problems, plant toxicity, and damage to certain materials at higher concentrations. The potential impact of photochemical formation refers to the release of chemicals that can contribute to this effect. The potential impact of photochemical formation is based on a simulated trajectory of ozone production in the troposphere with the existing Volatile Organic Compound (VOC). The potential impact of photochemical formation measures the specific chemical compared to the reference chemical ethene (Heijungs, 1995).

The next impact that is calculated in the cement production process is the impact of HTP. In Accordance with Table 10, the most significant value of HTP was generated by cement factory activities in scenario 1 with a yield value of $130.87 \mathrm{~kg} 1.4 \mathrm{DB}$-eq./ton cement. Along with the reduction in the use of coal, the results show that scenarios 2, 3, and 4 show the value of HTP is decreasing respectively with HTP value $119.69 \mathrm{~kg} 1.4 \mathrm{DB}-$ eq./ton cement, $117.74 \mathrm{~kg} 1.4 \mathrm{DB}$-eq./ton cement and $113.59 \mathrm{~kg} 1.4 \mathrm{DB}$-eq./ton cement. As Figure 4 shows, scenario 4 has the highest decline value which is $8.87 \%$. The HTP is a calculated index that reflects the hazard potential of a single chemical unit released into the environment and is based on the inherent toxicity of the compound and its potential dose. These by-products, especially arsenic, sodium dichromate, and hydrogen fluoride, are mainly due to the use of energy from fossil sources. These are chemicals that are potentially harmful to humans through inhalation, ingestion, and even contact. The potential for cancer, for example, is a problem here. This impact category is measured in 1.4-Dichlorobenzene (Aitor et al., 2015).

The ADP in Table 10 shows that the highest ADP value is produced by cement plant activities using scenario 1 fuel (single fuel) with an ADP value of $2355.38 \mathrm{MJ} /$ ton cement. As Figure 5 shows the lowest value is in scenario 4, which has a value of $2170.08 \mathrm{MJ} /$ ton cement. The lowest and highest values for the ADP impact indicate a reduction in the ADP impact along with a decrease in fossil fuels. According to Oers et al. (2002), the current approach to depletion of abiotic resources is based on the elements of materials and fossil fuels used. The material element approach is defined as depletion of the total natural resource $(\mathrm{kg})$ by not estimating its function. Meanwhile, the fossil fuel approach will estimate its function as the energy used, this approach depletes total energy used (MJ). 


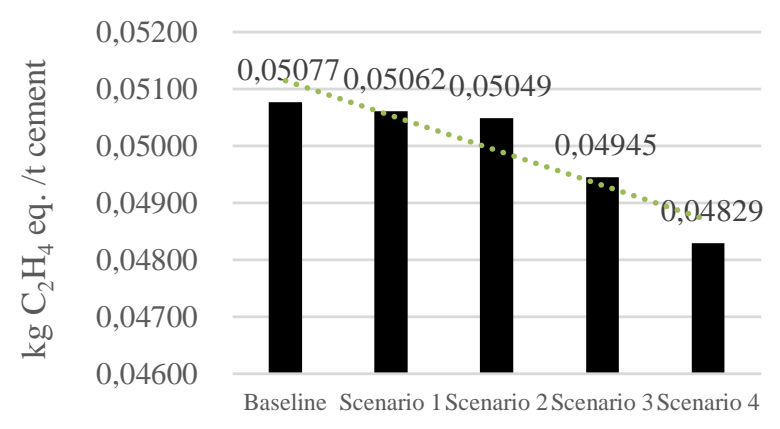

Figure 3 Results of POCP

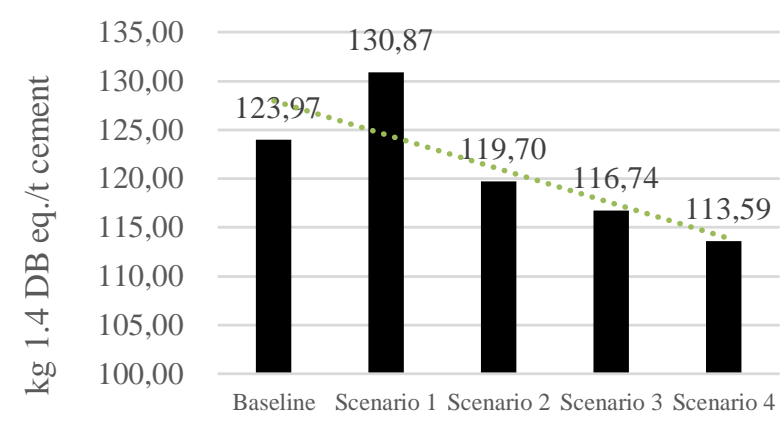

Figure 4 Results of HTP

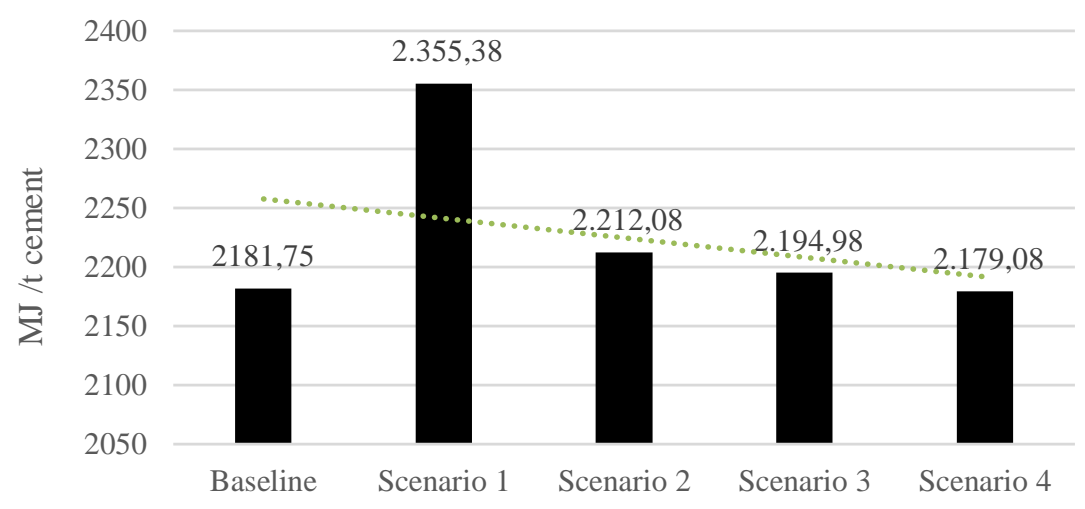

Figure 5 Results of ADP value

Based on overall interpretation then it can be seen that the kiln process unit contributes the highest emissions whereas the scenarios 4 has the most impact on the emission improvement. This was caused by the decrease use of fossil fuels and the increase of the use of alternative fuels into suitable composition. The use of RDF as alternative fuels for thermal energy which is believed reducing Green House Gas (GHG) emissions. Using RDF was solving domestic waste problems with the concept of waste to energy into the cement coprocessing. Hence the study objectives in regard to comparing baseline and other alternative scenarios in cement production activities at PT XYZ has complied with the concept of reducing GHG gas emission movement in the National Green Gas Action Plan (RAN GRK) and climate management as proclaimed in COP 21 Paris Agreement-UNFCCC.

\section{SWOT Analysis}

The formulation of this strategy answers the third research objective where the results of the identification of the internal and external environment of PT XYZ found seven (7) strengths, seven (7) weaknesses, seven (7) opportunities, and seven (7) threats. In addition, there are also three SWOT indicators, each found as additional indicators that strengthen the study related to SWOT of PT XYZ.

The internal factor evaluation consists of strength and weaknesses factor which has been correspondence and rated. Data results in Table 12 has shown profile of internal PT XYZ management system to overcome environment challenges. The company has collected certifications and fulfil requirement in regulation in Indonesia. One of the advantages that give strength point is the location of manufacture close with the raw material needed in the manufacturing cement. And also, the location is close with the alternative fuels producer therefore company as pioneer of use alternative fuels in Indonesia. The company runs emission reduction program with developing Green zone to have alternative fuels storage facility at site. Thus, alternative fuels will be used as fuels in clinker production by using coprocessing concept (Holcim, 2006). 
Table 12 Calculation of weighting Internal Factor Evaluation (IFE)

\begin{tabular}{|c|c|c|c|}
\hline \multirow[b]{2}{*}{ IFE key factors } & \multicolumn{3}{|c|}{ Value calculation } \\
\hline & Weight (B) & Rating (R) & $\begin{array}{l}\text { Scor } \\
(B \times R)\end{array}$ \\
\hline 1. Have environmental-related standards/certifications & 0.19 & 2.4 & 0.46 \\
\hline $\begin{array}{l}\text { 2. Cement products have SNI standards and green cement (low carbon } \\
\text { cement) }\end{array}$ & 0.14 & 2.8 & 0.38 \\
\hline 3. Availability of lime raw materials close to the factory site & 0.18 & 2.4 & 0.43 \\
\hline 4. Have AFR \& AMR utilization facilities & 0.12 & 2.0 & 0.25 \\
\hline 5. Having green zone facilities PT. XYZ & 0.12 & 2.0 & 0.25 \\
\hline 6. Running a $\mathrm{CO}_{2}$ emission reduction program & 0.12 & 2.0 & 0.25 \\
\hline $\begin{array}{l}\text { 7. Running the PT XYZ through the Co-Processing method as an integrated } \\
\text { waste management solution }\end{array}$ & 0.12 & 2.0 & 0.25 \\
\hline Total strengths $(\mathrm{S})$ & 1.00 & & 2.26 \\
\hline 8. Using coal as fuel from outside Java & 0.19 & 1.0 & 0.19 \\
\hline 9. Limited supply of alternative materials & 0.16 & 2.2 & 0.35 \\
\hline 10. High use of electricity for cement production & 0.15 & 1.0 & 0.15 \\
\hline $\begin{array}{l}\text { 11. The environmental impact of the Kiln process is a major contributor to } \\
\text { global warming }\end{array}$ & 0.15 & 1.4 & 0.21 \\
\hline $\begin{array}{l}\text { 12. The environmental impact of the co-processing technology has not been } \\
\text { identified }\end{array}$ & 0.12 & 1.4 & 0.17 \\
\hline 13. Optimization of emission reduction & 0.12 & 1.8 & 0.22 \\
\hline $\begin{array}{l}\text { 14. The CSR program that has been implemented has not been integrated } \\
\text { with environmental management }\end{array}$ & 0.12 & 1.0 & 0.12 \\
\hline Total weakness (W) & 1.00 & & 1.39 \\
\hline Total weight of IFE & & & 3.65 \\
\hline
\end{tabular}

The shown in previously the LCA study, the most challenging part of cement production is the high intensity of energy use e.g. fossil fuel usage and electricity. Whereas the source of main fuel is not close by the factory contributes also emission in transportation for the supply. Another challenge is the continuity of alternatives fuels which also contributes challenge in part of reducing emission in the factory. The technology of reducing $\mathrm{CO}_{2}$ has not yet reach economically use by using carbon capture storage (Jing et al., 2019) and waste heat recovery power generation (Semen Indonesia, 2018).

SWOT study has profiled the external factor evaluation in which consists of opportunities and threats for the company. Based on the Table 13 shows that the company has opportunity to develop utilization of renewable energy source by using RDF. The location of Bantargebang in Jakarta as domestic waste landfill facility has given opportunity to the company to acquire appropriate calorific value of waste as known as RDF (SBI, 2019). This innovation has successful role model in Cilacap facility whereas it has solving problem of alternative fuels and also solving domestic waste problem in local area (SBI, 2020). In regard with optimizing energy use and emission reduction program then company has opportunity to install the WHRPG (Waste Heat Recovery Power Generation) to the site. The WHRPG is expected to reduce $122-150 \mathrm{~kg} \mathrm{CO}_{2}$ eq. per year by using the recovery heat transferred to turbine generator (Semen Indonesia, 2018).

In regard with threats for the company then profile data (Table 13) has shown its obstacles and challenges. The natural disaster could damage whole process of cement manufacturing at site, e.g. earth quakes and landslide. The other threat is carrying capacity of environment in which caused by intensive of use of natural resources as raw material and fuels. In legal aspect then the Indonesian regulation has more stringent to regulate industry in regard with environment management system at the company. It has made company developing more innovation program to achieve and fulfill beyond regulation requirement (SBI, 2019). 
Table 13 Calculation of weighting External Factor Evaluation (EFE)

\begin{tabular}{|c|c|c|c|}
\hline \multirow[b]{2}{*}{ IFE Key Factors } & \multicolumn{3}{|c|}{ Value calculation } \\
\hline & Weight (B) & Rating (R) & $\begin{array}{l}\text { Score } \\
(\mathrm{BxR})\end{array}$ \\
\hline 1. Utilization of alternative energy as a renewable energy source & 0.14 & 2.0 & 0.29 \\
\hline 2. Optimization of energy consumption in production and support facilities & 0.14 & 2.0 & 0.29 \\
\hline 3. Cooperation with third parties producing waste with alternative materials & 0.14 & 3.0 & 0.43 \\
\hline 4. Utilization of waste as an alternative fuel & 0.14 & 3.0 & 0.43 \\
\hline 5. Conduct environmental innovations to reduce the impact of global warming & 0.14 & 2.4 & 0.34 \\
\hline $\begin{array}{l}\text { 6. Conduct studies on emission reduction and energy consumption } \\
\text { management }\end{array}$ & 0.14 & 1.4 & 0.20 \\
\hline $\begin{array}{l}\text { 7. Running an environmental management program that involves the } \\
\text { community }\end{array}$ & 0.14 & 1.0 & 0.14 \\
\hline Total opportunities $(\mathrm{O})$ & 1.00 & & 2.11 \\
\hline 8. Natural and non-natural disasters & 0.21 & 1.4 & 0.30 \\
\hline 9. Limited environmental carrying capacity & 0.17 & 1.6 & 0.28 \\
\hline $\begin{array}{l}\text { 10. Government policies/regulations related to the environment are } \\
\text { burdensome }\end{array}$ & 0.16 & 2.0 & 0.32 \\
\hline 11. PROPER assessment pressure from KLHK & 0.16 & 2.0 & 0.32 \\
\hline 12. Company contribution to SDG & 0.13 & 2.2 & 0.29 \\
\hline $\begin{array}{l}\text { 13. Environmental innovation programs from competing companies are more } \\
\text { innovative }\end{array}$ & 0.08 & 2.0 & 0.16 \\
\hline $\begin{array}{l}\text { 14. The success of reducing the emission of competitors is more effective and } \\
\text { efficient }\end{array}$ & 0.08 & 2.0 & 0.16 \\
\hline Total threats $(\mathrm{T})$ & 1.00 & & 1.83 \\
\hline Total weight of EFE & & & 3.94 \\
\hline
\end{tabular}

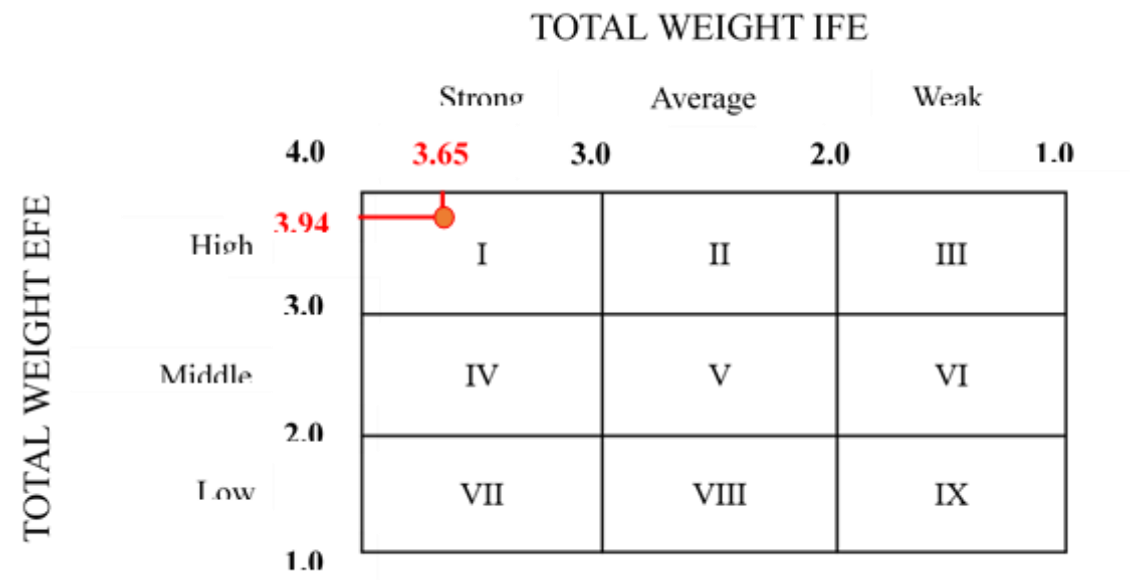

Figure 6 Internal external matrix SWOT analysis results

Based on David (2009) in Figure 6 then the value of IFE and EFE can be plotted in the matrix as a formula strategy of company to perform a sustain action of environment management system. Overall based on result data shown in Table 12 and 13 then the weight of internal factor evaluation (IFE) and external factor evaluation (EFE) has IFE value 3.65 and EFE 3.94 which is categorized as high/strong internal/external conditions because the company responds strongly to opportunities and threats that affect the company. 
The next stage after successfully determining the SWOT indicator is to match or combine internal strengths with external opportunities (S-O), internal weaknesses with external opportunities (W-O), internal strengths with external threats (S-T), and internal weaknesses with external threats (W-T). In Accordance with the third research objective then the results of the SWOT matrix analysis conclude twelve (12) strategies as follows.

a. Strength-Opportunity (S-O) Strategy

1) Strengthening the company's internal commitment to sustainable environmental management ( $\mathrm{S} 1, \mathrm{~S} 4$, S5, S7, O1, O3, O4)

2) Optimizing the best performance in environmental management with renewable innovations (S4, S5, S6, S7, O1, O4, O5)

3) Integrating holistic environmental management programs (S1, S2, S3, O3, O5, O6, O7)

b. Weakness-Opportunity (W-O) Strategy

1) Developing studies related to sustainable environmental management (W1, W2, O1, O2, O4, O5, O6)

2) Developing environmental innovations that are more innovative and have a significant impact on environmental performance (W2, W3, W4, W5, W6, O1, O2, O4, O5)

3) Strengthening networking and corporate cooperation in environmental management (W2, W7, O6, O7, O3)

c. Strength-Threat (S-T) Strategy

1) Having standards related to disaster risk management (S1, S2, S3, T1, T5, T4)

2) Educating consumers regarding the company's product value (S1, S2, S5, S7, T5, T6, T7)

3) Complying with all provisions/regulations related to the environment (S1, S2, S4, S5, S6, T3, T4)

d. Weakness-Threat (W-T) Strategy

1) Improving company performance in environmental management (W4, W5, W6, T3, T2, T5, T6, T7)

2) Optimizing the efficiency of using the primary raw materials and sources of electrical energy (W4, W5, W6, T2, T3, T4, T5)

3) Increasing the supply of renewable materials (W2, W1, T2, T4, T5, T6, T7)

\section{CONCLUSION}

The results show that the energy required to produce one tonne of cement products is 3.27 GJ with an emission impact of $760.11 \mathrm{~kg} \mathrm{CO}_{2}$ eq, AP $1.32 \mathrm{~kg} \mathrm{SO}_{2}$ eq, POCP $0.0508 \mathrm{~kg} \mathrm{C}_{2} \mathrm{H}_{4}$ eq, HTP $123.97 \mathrm{~kg}$ 1.4-DB eq dan ADP 2181.75 MJ. Based on the potential impact data, the highest contributor is produced by the kiln process unit. The current condition (baseline) is already reasonably good management but still has room for continuous improvement. The experimental results of alternative scenarios show that the fourth scenario with the addition of RDF alternative fuel has a relatively better reduction in environmental impact than other scenarios. The results of the four scenarios have GWP impact values of $757.41 \mathrm{~kg} \mathrm{CO}_{2}$-eq, AP impact values $1.19 \mathrm{~kg} \mathrm{SO}_{2}$-eq, POCP impact values $0.0482 \mathrm{~kg} \mathrm{C}_{2} \mathrm{H}_{4}$ eq, HTP impact values $113.59 \mathrm{~kg}$ 1.4-DB eq, dan ADP impact values $2170.08 \mathrm{MJ}$. The results of the identification of the internal and external environment of PT. XYZ found seven (7) strengths, seven (7) weaknesses, seven (7) opportunities, and seven (7) threats, respectively. The results of the SWOT matrix analysis produce twelve (12) strategies with the strategy applied in this condition is to support Growth-Oriented Strategy.

\section{REFERENCES}

[IEA] International Energy Agency. 2010. Energy Technology System Analysis Program [Internet]. [Downloaded 2021 Jan 18]. Available at: https://iea-etsap.org/ETechDS/PDF/I03_cement_June_2010_GS-gct.pdf.

[IEA] International Energy Agency. 2020. Cement Reports in 2020. Cement, IEA, Paris [Internet]. [Downloaded 2021 Jan 18]. Available at: https://www.iea.org/reports/cement. 
[ISO] International Standard Organization. 2006. ISO 14025 Environmental Labels and Declarations Principles and Procedures. Geneva (CH): ISO.

[ISO] International Standard Organization. 2016. ISO 14040 Environmental Management - Life Cycle Assessment - Principles and Framework. Geneva (CH): ISO.

[ISO] International Standard Organization. 2017. ISO 14044 Environmental Management - Life Cycle Assessment - Requirements and Guidelines. Geneva (CH): ISO.

[KLHK] Kementerian Lingkungan Hidup dan Kehutanan. 2012. Pedoman Penyelenggaraan Inventarisasi Gas Rumah Kaca Nasional. Jakarta (ID): KLHK.

[SBI] Solusi Bangun Indonesia. 2019. Sustainability Report. Jakarta (ID): PT. Solusi Bangun Indonesia.

[SBI] Solusi Bangun Indonesia. 2020. Sustainability Report. Jakarta (ID): PT. Solusi Bangun Indonesia.

Aitor P, Rodríguez C, Ciroth A. 2015. Impact Assessment Methods in Life Cycle Assessment and Their Impact Categories. Berlin (DE): GreenDelta GmbH.

Alfarizi Y, Budiadi, Paramitha T. 2020. Analisis geokimia XRF untuk menentukan kualitas batu gamping di Bukit Tarjarang PT. Semen Padang [thesis]. Yogyakarta (ID): Institut Teknologi Nasional Yogyakarta.

Alsheyab MAT. 2013. Analysis of The Potential Use of Major Refusederived Fuels in Jordan as Supplementary Fuel. Qatar (TR): Qatar National Research Fund.

Boumanchar I. 2018. Municipal Solid Waste Higher Heating Value Prediction from Ultimate Analysis Using Multiple Regression and Genetic Programming Techniques. Marocco (tZA): Chouaïb Doukkali University.

Cankaya S, Pekey B. 2018. Comparative life cycle assessment of clinker production with conventional and alternative fuels usage in Turkey. International Journal of Environmental Science and Development. 9(8): 213-217.

Chen C, Habert G, Bouzidi Y, Jullien A. 2010. Environmental impact of cement production: detail of the different processes and cement plant variability evaluation. Journal of Cleaner Production. 18(5): 478485 .

Damayanti R. 2018. Abu batu bara dan pemanfaatanya: Tinjauan teknis karakteristik secara kimia dan toksikologinya. Jurnal Puslitbang Teknologi Mineral dan Batu Bara. 14(3): 213-231.

David F. 2009. Manajemen Strategis: Konsep. Edisi 13. Jakarta (ID): Salemba Empat.

Gabel K, Forsberg P, Tillman AM. 2004. The Design and Building of a Life Cycle-Based Process Model for Simulating Environmental Performance, Product Performance and Cost in Cement Manufacturing. Gothenburg (SE): Chalmers University of Technology.

Hacatoglu K. 2014. A New Model to Assess the Environmental Impact and Sustainability of Energy Systems. Canada (US): University of Ontario Institute of Technology.

Harjanto T, Fahrurrozi M, Bendiyasa M. 2012. Life cycle assesment pabrik semen PT. Holcim Indonesia Tbk. Pabrik Cilacap: Komparasi antara bahan bakar batubara dengan biomassa. J Rekayasa Proses. 6(2): 5158.

Heijungs R. 1995. A Proposal for The Definition of Resources Equivalency Factors for Use in Product Life Cycle Assessment. Belanda (NL): Leiden University.

Hernowo P, Astuti N, Mahardika AP, Sutoyo Y. 2017. Pengukuran nilai kalor biomasa bahan baku biofuel. Jurnal Teknologi. 6(1): 2088-3315.

Holcim. 2006. Guidelines on Co-procesing Waste Materials in Cement Production [Internet]. Jerman (DE): Deutsche Gesellschaft für Technische Zusammenarbeit GmbH (GTZ). [Downloaded 2020 Dec 20]. Available at: umwelt-infrastruktur@gtz.de/www.gtz.de.

Huntzinger DN, Eatmon TD. 2009. A life cycle assessment of portland cement manufacturing: Comparing the traditional process with alternative technologies. Journal of Cleaner Production. 17(7): 668-675. doi: https://doi.org/10.1016/j.jclepro.2008.04.007.

Indonesian Cement Association. 2018. Cement Industry in Indonesia [Internet]. [Downloaded 2021 Jan 3]. Available at: https://asi.or.id/cement-industry-in-indonesia/\#.

Indonesian Government. 2016. Undang-Undang No. 16 Tahun 2016 tentang Persetujuan Paris Atas Konvensi Kerangka Kerja Perserikatan Bangsa-Bangsa mengenai Perubahan Iklim. Lembaran Negara RI Tahun 
2016. Jakarta (ID): State Secretariat.

Indonesian Government. 2011. Peraturan Presiden No. 11 Tahun 2011 tentang Rencana Aksi Nasional Penurunan Emisi Gas Rumah Kaca. Jakarta (ID): State Secretariat.

Indonesian Government. 2012. Kementrian Perindustrian no. 12 Tahun 2012 tentang Peta Panduan Pengurangan Emisi $\mathrm{CO}_{2}$ Industri Semen di Indonesia. Jakarta (ID): State Secretariat.Jing A, Middleton RS, Li. 2019. Environmental Performance Analysis of Cement Production with $\mathrm{CO}_{2}$ Capture and Storage Technology in a Life-Cycle Perspective. Shenyang (CN): Northeastern University.

Kartikasari D. 2016. Power plant emissions inventory in Batam. Proceeding Seminar Nasional Teknologi Energi Nuklir 2016; 2021 Jan 18; Batam, Indonesia. Batam (ID): Badan Tenaga Nuklir.

Lehne J, Preston F. 2018. Making Concrete Change Innovation in Low-carbon Cement and Concrete. London (GB): The Royal Institute of International Affairs Chatham House 10 St James's Square.

Maharani VS. 2019. Kajian Life Cycle Assessment (LCA) produksi semen Pabrik X [thesis]. Surabaya (ID): Institut Teknologi Sepuluh Nopember Surabaya.

Nadal, Schuhmacher M, Domingo JL. 2009. Cost Benefit Analysis of Using Sewage Sludge as Alternative Fuel in a Cement Plant: a Case Study Environ. Sci Pollut Res. 16: 322-328.

Nugraha AZ. 2017. Life Cycle Assesment (LCA) produk semen di PT. Indocement Tunggal Prakarsa [thesis]. Bogor (ID): Sekolah Pascasarjana Institut Pertanian Bogor.

Octova A. 2019. Analisis Konsumsi Bahan Bakar Dump Truck Nissan CWM330 pada penambangan batu bara PT. Nan Riang [thesis]. Padang (ID): Universitas Negeri Padang.

Oers VL, de Koning A, Guinee JB, Huppes G. 2002. Abiotic Resource Depletion in LCA. Belanda (NL): Road and Hydraulic Engineering Institute.

Paramita W. 2018. Sustainability of refuse derived fuel potential from municipal solid waste for cement's alternative fuel in Indonesia (A Case at Jeruklegi Landfill, in Cilacap) [thesis]. Jakarta (ID): University of Indonesia.

Qola AD. 2020. Life Cycle Assesment (LCA) cradle to gate produksi batu bara di PT. XYZ Kalimantan Selatan [thesis]. Bogor (ID): IPB University.

Rebitzer G, Ekvall T, Frischknecht R, Hunkeler D, Norris G, Rydberg T, Pennington DW. 2004. Life cycle assessment. Environment International. 30(5): 701-720. doi: 10.1016/j.envint.2003.11.005.

Semen Indonesia. 2018. WHRPG “Green Electricity” [Internet]. [Downloaded 2021 Feb 28]. Available at: http://jcm.ekon.go.id/. Abrar R, Bindar Y, Susanto H, Sasongko D. 2017. Pengaruh Kadar Karbon pada Proses Gasifikasi. Jakarta (ID): Universitas Tarumanagara.

Stafford, Fernanda N. 2015. Life Cycle Assessment of the Production of Portland Cement: A Southern Europe Case Study. Florianopolis (BR): Federal University of Santa Catarina (UFSC).

Yunianto IT. 2018. Freight calculation model: A case study of coal distribution [thesis]. Surabaya (ID): Sepuluh Nopember Institute of Technology.

Zhang DD, Lee HF, Wang C, Li B, Pei Q, Zhang J, An Y. 2011. The Causality Analysis of Climate Change and Large-Scale Human Crisis. Hong Kong (HK): University of Hong Kong. 